\section{Religious tolerance: A view from China}

Philosophy and Social Criticism

2019, Vol. 45(4) 469-476

(C) The Author(s) 2019

Article reuse guidelines: sagepub.com/journals-permissions DOI: I0.1I77/019|4537|9828775

journals.sagepub.com/home/psc

@SAGE

\author{
Francesca Tarocco
}

Cà Foscari University of Venice, Italy

\begin{abstract}
European and North American cultures are awash in stereotypes about religion. The recently published volume Stereotyping Religion: Critiquing Clichés (2017) tackles several of these and shows why scholars find them to be clichéd. By describing their origins and elucidating the social or political work they rhetorically accomplish in the present, the authors of the volume address some important clichés, namely, that religions are belief systems, that religion is a private matter or that it exclusively concerns the transcendent. In the same way, scholars of religion in the Chinese speaking world find themselves often having to dispel the many myths that surround it. Does China have religion? What does it look like? And where does it stand vis-à-vis religious tolerance? In this short article, I take a comparative look at the late imperial period in China and the substantive changes that took place at the end of it. What does religious tolerance - and its opposite - mean in the context of China's modern epistemic order?
\end{abstract}

\title{
Keywords
}

China, modernity, religion, secularism, tolerance

\section{Religions and secularisms}

When did questions about religion and about religious tolerance begin to emerge? Wilfred Cantwell Smith, one of the first scholars who drew attention to the artificial nature of the category religion, writes, "The concept "religion," then, in the West has evolved. Its evolution has included a long-range development that we may term a process of

\footnotetext{
Corresponding author:

Francesca Tarocco, Associate Professor of Buddhist Studies and Chinese Religious Studies, Cà Foscari University of Venice, Department of Asian and North African Studies, Palazzo Vendramin, Dorsoduro 3462, Venice 30123, Italy.

Email: francesca.tarocco@unive.it

A version of this article was presented at the Venice Seminars 2018 ("Fountainheads of Toleration - Forms of Pluralism in Empires, Republics, Democracies") that were organized by Reset-Dialogues on Civilizations in partnership with the Giorgio Cini Foundation, Nomis Foundation, Ca' Foscari University of Venice and its International Center for the Humanities and Social Change. The Venice Seminars took place at Giorgio Cini Foundation and Ca' Foscari University of Venice from June 7-9, 2018.
} 
reification: mentally making religion into a thing, gradually coming to conceive it as an objective systematic entity'. ${ }^{1}$ In Europe, notes Wendy Brown, the idea of religious tolerance was coined in the nineteenth century in the context of the discursive construction of Judaism in order to 'incorporate while regulating differences in belief'. Crucially, it 'simultaneously permitted individual and group regulation, that is, it facilitated the marking of a difference through which both the incorporation and the individuation required for regulation could be sustained'. Nation-state consolidation and its attending discourses of abstract universal citizenship ultimately rested around Christian, bourgeois, white, heterosexual norms (Brown 2004: 21-22). In fact, ideas of religion and of religious tolerance look quite different if one considers Asia, Europe or the United States.

For decades, critical social theorists have debated the nature and place of religion in modernity and examined religious cultures in light of what was once called the 'secularization thesis' (de Vries 1999; Berger 1999). What has emerged from these debates is a rather more nuanced picture of the workings of secular and religious forces, along with the increased appreciation of their interdependence. Max Weber's account of modernity, along with its associated secularization thesis - the idea that modernity necessarily causes the declining of religion from public life - has not been borne out on a large scale. Similarly, Joseph Blankholm notes that the particular notion of secularism discussed by Talal Asad (2003) and Janet Jakobsen and Ann Pellegrini (2000, 2008) only looks at how it centres on 'prohibiting religion from certain spaces' and 'privileging specific ways of being religious' $(2018,245)$. Genealogical investigations of the secular have in fact shown 'how secular people's belief-centered approach to (non) religious identity is in part a product of a distinctly Protestant and American form of secularism ... though its deeper origins lie in colonialist and broader Christian conceptions of religion' (Blankholm 2018: 246). Rather than seeing secularization as an inevitable process of privatization of religion in the face of modernization, more recently scholars emphasize geographically differentiated processes in which societies embrace certain aspects that might fall into the category of the 'secular' and the 'religious'. The relationship between the two is constantly renegotiated in each national and legal context (Bubandt and von Beek 2012; Ji 2008). Intriguingly, Weber discussed Confucianism in terms of 'orthodoxy' and the imperial state. Daoism, he identified as 'heterodoxy', presupposing a radical difference and incompatibility between the two.

In fact, religion and the plural religions did not actually begin to take on their present meanings until the 17th century. In many important ways, the notion that there are 'religions' characterized by discrete sets of propositional beliefs and practices is connected with the European Enlightenment and emerged in the wake of the postReformation fragmentation of Christianity with its attending anxieties about comparing and contrasting sectarian identities. ${ }^{2}$ It was during this period that Europeans discovered Asian religions. In The Birth of Orientalism, Urs App's notes that such discovery was 'the result of a long process that around the turn of the eighteenth century produced a paradigm change' (2010: xiii). App's case studies illustrate the centuries-long, gradual emancipation of European thinkers from the cultural horizon of the Bible. Between 1574 and the 1750s, even before they became aware of Buddhist texts in Sanskrit, some Europeans studied, learned about and even translated Buddhist texts from literary Chinese and Tibetan (2010: 190). 
As T. H. Barrett and I have shown, at the time of the earlier encounters between Europeans and East Asians, notions surrounding religious terminology required complex 'translingual' negotiations. ${ }^{3}$ Words travelled and changed. The lexical, let alone conceptual, equivalent of the modern English term religion most certainly did not exist at the time of João Rodrigues's stay in Japan or of Matteo Ricci's in China. On the contrary, its first occurrence as a neologism in literary Chinese to mean something similar to what is meant today can be dated to the mid-nineteenth century at the earliest. The creation of new terminology necessitated the involvement and agency of many different individuals and many different texts from Asia, Europe and North America - from Buddhist monks and Buddhist medieval texts, to Christian missionaries, to Chinese and Japanese bureaucrats, to colonial officers. Whatever the effects of later developments, the word for 'religion' in East Asia was not invented ex novo overnight but rather emerged over the course of a long period of linguistic and conceptual instability. This phenomenon needs to be grasped accurately in order to construct a reliable genealogy of religion for China and East Asia, and even to understand how Europe and North America make sense of East Asian religion (Barrett and Tarocco 2012).

Crucially, the idea of 'religion' in its 18th-century European formulation of an exclusive affiliation to a clerical - and sacramental, in the case of Catholicism - religious organization would have been very disconcerting to women and men living in the vast late imperial Chinese empire. Only a relatively small number of clerics and highly committed lay people identified exclusively with one of the three institutionalized Chinese religions, Buddhism, Confucianism and Daoism. The rest practiced what $\mathrm{C}$. K. Yang in his 1961 classic Religion in Chinese Society calls 'diffused religion'. This is associated with multiple local worshipping communities based around family lineage halls, communal village temples and temples dedicated to local heroes and deities. 4 Today, most scholars simply refer to this system as 'Chinese religion'. When one looks closely at how Chinese religion is actually practiced, the 'three teachings' (san jiao) model of identifying and understanding Buddhism, Daoism and Confucianism as neatly separate spheres of action begins to break down. Adam Chau has argued persuasively that Chinese religion can in fact be more usefully demarcated by modalities of practice for instance, the liturgical modality or the self-cultivation modality - than by the specific doctrinal contents or iconographies of the three teachings (Chau 2011).

\section{Orthodoxy and heterodoxy in late imperial China}

Scholars of Chinese religion identify its distinguishing feature, grounded in cosmological theory, as ling, meaning 'power' or 'efficacy', 'that which is of celestial origin'. People worship the gods to get things done: when there is solicitation (gan), there is response (ying). The world is one vast 'resonant body'. Many festivals and, of course, many gods are worshipped in the course of the liturgical lunar year. At a very fundamental level, Chinese practitioners value the gods because of their ability to perform miracles (Lagerway 1987; Feuchtwang 2001; Dean 1993). Late imperial China was characterized by the more or less pacific coexistence of hundreds of deities and worthies and by a myriad of religious spaces, temples and shrines. By the Ming period (13681644), potent local spirits and other forces had been anthropomorphized and had entered 
a vast and heterogeneous trans-local pantheon that included Buddhist and Daoist deities, female and male gods. Several of these were granted bureaucratic and royal titles, the Jade Emperor, the Medicine King, The Dragon King, the Wealth God and so on. Both popular piety and imperial patronage were made manifest in the substantial number of religious structures that marked the Chinese landscape. In her remarkable study of religious structures in Beijing as a sacred city between 1400 and 1900, Susan Naquin traced and documented the social and religious life of more than 2500 temples. According to some recent estimates, less the $10 \%$ have survived decades of persecution since the beginning of the twentieth century (Goossaert and Palmer 2011).

Some scholars have argued that the high degree of cultural unification reached in China throughout the late imperial period was due to a large extent to the collective participation of Chinese people to ritual routines. In other words, as James Watson and Evelyn Rawski have suggested, the standardization of ritual was crucial to the creation and maintenance of a unified Chinese culture (1988). In his well-known study of Chinese religion The Imperial Metaphor, Stephen Feuchtwang writes: 'propriety and impropriety (zheng and xie), order and chaos (anping and luan) ... in any activity, but particularly in ceremony, have been central to Chinese problems of authority and of identification with that authority (belonging to a community, local or imperial)' (2001: 10). Mandated by Heaven (tian) to rule, any emperor was expected to maintain or restore social and cosmic harmony through his ritual role by making sacrifices to Heaven, cosmic deities and the imperial ancestors listed in the registry of state sacrifices. Such balance between human society and the cosmological order was key to preserving power. In Confucian parlance, it was the emperor's obligation to protect 'orthodoxy' (zheng) and to intervene and suppress 'heterodoxy' (xie). Not unlike the modern Communist Party official, the late imperial Chinese bureaucrat feared social chaos (luan) and religiously motivated uprising.

And yet, ritual did not just contribute to reinforcing state-centred cosmologies. For instance, if, on the one hand, the imperial state exercised a strict control over funerary and other rites, variations were also allowed. No single overarching system organized all the gods of Chinese religion in a unified pantheon and there was conspicuous variation over space and time. 'A fundamental pluralism of belief was not easily standardized - as the world of the gods was plural, so was that of the believers' (Naquin 2000, 39). Worshipers had numerous ritual options. In fact, in China, religious pluralism ultimately rests on the coexistence of, and competition between, providers of ritual services. The quest for ling (efficacy) prompted practitioners, for instance, in the context of a funeral, to hire ritual specialists belonging to various traditions to maximize the potency of the rite. During the late imperial period, Buddhist, Daoist and Confucian clerics only occasionally were in a position - vis-a-vis the state - to openly antagonize one another, but when they were, they did try to. Doctrinal exclusivity was not unheard of. For instance, it took the guise of indigenous millenarian movements, active since the first centuries of the Common Era and of Middle Eastern monotheisms. Islam was brought to Chinese territories in the 8th century and was well established by Ming times, a time that also witnessed the arrival in Macau of Italian and Portuguese Jesuit missionaries, who eventually reached the imperial court in Beijing in $1601 .^{5}$ 
In the 18th century, the imperial project of the Manchu rulers whose multi-cultural and multi-religious empire, the Qing (1644-1912), was characterized by the rigorous control and co-optation of religious forces, especially those with trans-national ties, included the Buddhist Yellow Hats in Tibet and Islam in the then newly named Xinjiang (literally, New Border) province. The Qing emperors attempted to exert a monopoly on all religious spheres and exerted as tight a control as they could over anyone who claimed to have a special relationship with the spirit world. ${ }^{6}$ The role of ritual was central in legitimizing the dynastic mandate to rule as well as reinforcing state authority and power on all levels (Zito 1997). As Philip Kuhn's analysis of the sanctions against sorcery, magic and witchcraft in penal code also reveals, Qing officialdom was determined to protect its prerogative to communicate with the spirit world as well as dictate how others should conduct such communication. ${ }^{7}$

\section{Intolerance}

The elites that eventually seized power at the end of the imperial era and who were fervent nationalists associated China's military weakness to what they saw as the nation's religious and political 'backwardness'. Being patriotic, especially among China's urban intellectuals, often meant the outright rejection of many aspects of mainstream religious life and practice. The assault on religion intensified with the fall of the last dynastic power and the establishment of the Republic. As a whole, however, the traditional practices of Chinese religion continued, although in some areas temples were converted to schools or other nonreligious uses. It is important to note that, during the period of the Republic, hostility to traditional elite and popular religious practices and institutions was shared across a broad political spectrum. Nationalists, liberals, socialists and even warlords might violently oppose each other politically and ideologically, but they shared common hostility to and contempt for communal religion and other so-called backward customs. In fact, Marxism-Leninism was not the sole source of the antireligious attitudes and policies of the founders of the Communist party. The formulation zheng versus xie, orthodoxy/heterodoxy started to change in the early 1900s. Heavily influenced by the Christian model, the ruling elites favoured institutional and clerical religions. This shift had terrible consequences for all other religious communities. ${ }^{8}$

The novel discourse of religion was based around the use of neologisms that circulated between China, Japan, Europe and the United States. Translations could never be a linear process of conversions of concepts from a guest to a host language. They were sites for both contestation and negotiation and new meanings and ideas were injected into the translation process (Liu 2004; Tarocco 2008; Barrett and Tarocco 2012). Two neologisms - religion (zongjiao; Japanese shükyō) and superstition (mixin; Japanese meishin) - helped redefine religious practice in China. A religion, in this new context, was understood to be a church-like system of doctrine separate from other realms of society, while 'superstition' replaced 'heterodoxy' as an undesirable set of practices potentially harmful to the whole of society and that ought to be eradicated. This bifurcation laid the groundwork for many anti-religious campaigns in the decades to come, when whatever was not grounded in and strictly limited to the practices and scriptures of clerical religions - Christianity, Islam, Buddhism - became the target of the state 
(Goossaert and Palmer 2011). The discursive coupling of religious reform with national progress produced devastating changes in the life of religious practitioners. Although the influence of post-Reformation Christianity is evident in the adaptation and evolution of terms such as zongjiao and mixin, this was not simply a confrontation between atheists versus believers, it was also a religious project in which elite practitioners proposed competing religious visions in answering the question as to how China would enter the modern world of nations (Litzinger 1996).

The last decade of the nineteenth century and the first decades of the twentieth century brought great changes to the world of Chinese religion. The late Qing state and its Republican successors sought to confiscate temple properties and to replace the institutions of local religion with schools and police stations. By falling under the influence of Western secular models of church/state separation and negotiating with a limited number of officially recognized membership-based religious traditions to the exclusion of community-based and other ritual modes, the modern Chinese state reconfigured the religious field (Nedostup 2009; Poon 2011). What was deemed then and now a politically unacceptable form of religion was (is) targeted by violent action. The use of the term zongjiao - now pervasive - is still contested because of its calamitous skewing of the meaning of religion for the East Asian language speaker in the direction of the beliefs and ideologies of the professional clerical groups representing such religions as Buddhism and Christianity. Only with some difficulty can it create a semantic sphere that includes the practices of the majority of the Chinese population.

Novel religious policies - the implementation of political ideals that favour certain institutions and religious practices over others - are at variance with those favoured by the imperial state, let alone by the majority of the population, up to c. 1900. The processes of 'pseudo-sacralization' of the state, in Thomas Dubois' words, are visible in other modern Asian states, for instance, in Sukarno's Indonesia. It is clear by now, however, that the efforts to eradicate religion, particularly virulent in Mao's China, have almost completely failed (Chau 2006). To a certain extent, the modern reinvention of five clear-cut institutional traditions - Islam, Buddhism, Catholicism, Protestantism, Daoism - does retain political and social meaning, at least for the educated elites. In urban Asia, even if modernizers have tried to promote a form of secular nationalism, the presence of some crucial aspects of religion and the revival of others are especially evident. Also, communal religion has made a powerful comeback. Importantly, Chinese women, the protagonists of many of China's religious revivals, have used whatever religious resources they have at their disposal to define religion, religious tolerance, secularism and modernity in their own terms. Practitioners give new meanings to - and in the process are also empowered by - the continuing diversity of the modern Chinese religious landscape.

\section{ORCID iD}

Francesca Tarocco (D) https://orcid.org/0000-0002-6918-8940

\section{Notes}

1. Wilfred Cantwell Smith $(1978,51)$.

2. See Harrison (1990), McCutcheon (1995, 285-301) and Lash (1996).

3. See Lydia Liu (2004). 
4. See Yang $(1961,296-300)$.

5. See Naquin $(2000,20,38)$. For examples from contemporary North China, see Chau (2005). For Islam, see Lipman (1997). For Catholic communities in late nineteenth century rural China, see Litzinger (1996, 41-52). For Christianity in the pre-modern period, see Standaert (2001). For popular movements, see Seiwert (in collaboration with Ma Xisha) (2003).

6. See Waley-Cohen $(1998,336-52)$.

7. See Kuhn (1990).

8. See, for example, Nedostup (2009); Poon (2011); Tarocco (2008, 42-56).

\section{References}

App, Urs. 2010. The Birth of Orientalism. Philadelphia: University of Pennsylvania Press.

Asad, Talal. 2003. Formations of the Secular: Christianity, Islam, Modernity. Stanford, CA: Stanford University Press.

Berger, Peter L., ed. 1999. The Desecularization of the World: Resurgent Religion and World Politics. Grand Rapids, MI: Wm. B. Eerdmans Publishing Company.

Brown, Wendy. 2004. “Tolerance and/or Equality? The 'Jewish Question' and the 'Woman Question'." Differences: A Journal of Feminist Cultural Studies 15, no. 2 (Summer 2004): 1-31.

Blankholm, Joseph. 2018. "Secularism and Secular People." Public Culture 30, no. 2, 245-268.

Bubandt, Nils, and Martijn von Beek. 2012. Varieties of Secularism in Asia: Anthropological Explorations of Religion, Politics and the Spiritual. Abingdon: Routledge.

Chau, Adam Yuet. 2005. Miraculous Response: Doing Popular Religion in Contemporary China. Stanford: Stanford University Press.

Chau, Adam Yuet. 2006. Miraculous Response: Doing Popular Religion in Contemporary China. Stanford: Stanford University Press.

Chau, Adam Yuet. 2011. "Modalities of Doing Religion." In Chinese Religious Life, edited by David A. Palmer, Glenn L. Shive, and Philip L. Wickeri, 67-84. Oxford: Oxford University Press.

Dean, Kenneth. 1993. Taoist Ritual and Popular Religion in Southeastern China. Princeton: Princeton University Press.

Dean, Kenneth. 2003. (co-authored with Thomas Lamarre). "Ritual Matters." In Traces 3: Impacts of Modernity, edited by T. Lamarre, 257-84. Hong Kong, Chinese University of Hong Kong Press.

De Vries, H., 1999. Philosophy and the Turn to Religion. Baltimore, MD: The Johns Hopkins University Press.

Feuchtwang, Stephen. 2001. Popular Religion in China: The Imperial Metaphor. London: Curzon. Goossaert, Vincent, and David A. Palmer. 2011. The Religious Question in Modern China. Chicago: University of Chicago.

Harrison, Peter. 1990. "Religion" and the Religions in the English Enlightenment. Cambridge: Cambridge University Press.

Jakobsen, Janet R., and Pellegrini Ann. 2000. "World Secularisms at the Millennium: Introduction." Social Text 18, no. 3: 1-27.

Jakobsen, Janet R., and Pellegrini Ann. eds. 2008. Secularisms. Durham, NC: Duke University Press.

Ji, Zhe. 2008. "Secularization as Religious Restructuring: Statist Institutionalization of Chinese Buddhism and Its Paradoxes." In Chinese Religiosities: Afflictions of Modernity and State Formation, edited by Mayfair Mei-hui Yang, 233-60. Berkeley: University of California Press. 
Kuhn, Philip A. 1990. Soulstealers: The Chinese Sorcery Scare of 1768. Harvard: Harvard University Press.

Lagerwey, John. 1987. Taoist Ritual in Chinese Society and History. New York: Macmillan Publishing Company.

Lash, Nicholas. 1996. The Beginning and End of "Religion”. Cambridge: Cambridge University Press.

Lipman, Jonathan N. 1997. Familiar Strangers: A History of Muslims in Northwest China. Seattle: University of Washington Press.

Litzinger, A. 1996. "Rural Religion and Village Organization in North China: The Catholic Challenge in the Late Nineteenth Century." In Christianity in China. From the Eighteenth Century to the Present, edited by Daniel H. Bays, 41-52. Stanford: Stanford University Press.

Liu, Lydia. 2004. Translingual Practice; The Clash of Empires: The Invention of China in Modern World Making. Cambridge, MA: Harvard University Press.

McCutcheon, Russell. 1995. "The Category 'Religion' in Recent Publications: A Critical Survey." Numen 42: 285-301.

Naquin, Susan. 2000. Peking: Temples and City Life, 1400-1900, 20, 38. Berkeley: University of California Press.

Nedostup, Rebecca. 2009. Superstitious Regimes: Religion and the Politics of Chinese Modernity. Cambridge: Harvard University Asia Center.

Poon, Shuk-Wah. 2011. Negotiating Religion in Modern China: State and Common People in Guangzhou, 1900-1937. Hong Kong: Chinese University Press.

Seiwert, Hubert. 2003. (in collaboration with Ma Xisha), Popular Religious Movements and Heterodox Sects in Chinese History. Leiden: Brill.

Smith, Wilfred Cantwell. 1978. The Meaning and End of Religion. London: SPCK.

Standaert, Nicolas. ed. 2001. Handbook of Christianity in China: Volume One: 635-1800. Leiden, Boston, Koln: Brill.

Tarocco, Francesca. 2008. “The Making of 'Religion' in Modern China.” In Religion, Language, and Power, edited by Nile Green, and Mary Searle-Chatterjee, 42-56. New York: Routledge.

Tarocco, Francesca, and T. H. Barrett. 2012. "Terminology and Religious Identity: The Genealogy of the Term Zongjiao." In Dynamics in The History of Religions Between Asia and Europe, edited by Volkhard Krech, and Marion Steinicke, 307-319. Leiden: Brill.

Waley-Cohen, Joanna. 1998. "Religion, War, and Empire-Building in Eighteenth-Century China." The International History Review 20, no. 2 (June): 336-52.

Watson, James L., and Evelyn S. Rawski. 1988. Death Ritual in Late Imperial and Modern China. Berkeley: University of California.

Yang, C. K. 1961. Religion in Chinese Society: A Study of Contemporary Social Functions of Religion and Some of Their Historical Factors, 296-300. Berkeley: University of California Press.

Zito, Angela. 1997. Of Body and Brush: Grand Sacrifice as Text/Performance. Chicago: University of Chicago Press. 